\title{
Strategies for Developing NADH Detector Based on Meldola Blue in Different Immobilization Methods: A Comparative Study
}

\author{
Marcela P. Mariotti, ${ }^{*}$ Carla dos S. Riccardi, Fernando L. Fertonani and Hideko Yamanaka \\ Instituto de Química, Universidade Estadual Paulista, CP 355, 14800-900 Araraquara - SP, Brazil
}

\begin{abstract}
Foi realizado um estudo comparativo entre duas metodologias de imobilização do Azul de Meldola (MB), utilizado para diminuir o potencial de oxidação do NADH. O estudo foi realizado no eletrodo de carbono vítreo através da eletropolimerização do pirrol e $\mathrm{MB}$, empregando a técnica de voltametria cíclica e avaliando-se o efeito do número de ciclos para definir a espessura e a estabilidade do filme. Com 25 ciclos foi obtido o melhor resultado. Foi também investigada a modificação do eletrodo de grafite com filme formado pelo sistema sol-gel PPO 300 ou PPO 4000 pelo método de recobrimento por mergulho, através de dois métodos: oclusão e adsorção. $\mathrm{O}$ melhor método foi o de adsorção da MB durante $10 \mathrm{~min}$, seguida de depósito do filme PPO 300, favorecido pelo tempo de secagem (24 horas). A adsorção da MB seguido do depósito do PPO 300 apresentou maior intervalo linear do que a metodologia do PPY.
\end{abstract}

A comparative study was accomplished between two immobilization methodologies for the meldola's blue (MB), used to decrease the oxidation potential of NADH. The study was performed with glassy carbon electrode by electropolymerization of pyrrole and MB through the technique of cyclic voltammetry being evaluated the effect of the number of cycles to define the thickness and the stability of the film. With 25 cycles it was obtained the best result. They were also investigated the modification of the graphite electrode with film formed by the system sol-gel PPO 300 or PPO 4000 for the dip-coating, through two methods: occlusion and adsorption. The best method was it of adsorption of MB during $10 \mathrm{~min}$, following by deposit of the film PPO 300 , favored for the time of drying (24 hours). The adsorption of MB followed by PPO 300 deposition presented broader linear range than PPy methodology

Keywords: meldola's blue, NADH, polypyrrole film, electropolymerization, Sol-Gel process

\section{Introduction}

In recent years, the electrochemical oxidation of $\mathrm{NAD}(\mathrm{P}) \mathrm{H}$ has found increasing interest due to its importance in analytical assays, bioprocess control, and preparative enzymatic synthesis. ${ }^{1} \mathrm{NAD}(\mathrm{P})$ dependent enzyme, trivially called dehydrogenase (C.E. 1.6) constitute the largest group of enzymes known: their number is more than $500 .^{2}$

Problems associated with the direct oxidation of $\mathrm{NADH}$ on the electrode surface have resulted in the development of several strategies to obtain mediator modified electrode surfaces $^{3}$ where the electrocatalytic oxidation of NADH can take place at much lower overvoltages decreasing the effects of products adsorption and side reaction resulting in the formation of enzymatically active $\mathrm{NAD}^{+}$and also providing a high selectivity for amperometric detection of

*e-mail: marcmari@posgrad.iq.unesp.br
NADH. ${ }^{4}$ Some compounds, such as quinines, ${ }^{5}$ alkylphenezinium ions ${ }^{6}$ and phenoxazine derivatives, ${ }^{7}$ have been used as mediators for this purpose. Gorton and co-workers have extensively studied the electrocatalytic properties on NADH oxidation of different phenazines, phenaxazines and phenothiazines..$^{8-9}$ Many articles also describe the use of such modified electrode in conjunction with dehydrogenases and their use for biosensor development. ${ }^{10,11}$

Among the mediators taken into consideration when designing biosensors, meldola's blue counts as a well studied, extensively used compound, being most famous for facilitating NADH oxidation. This mediator allows to achieve high sensitivity for the amperometric determination of NADH and to detect as low as $2 \times 10^{-6} \mathrm{~mol} \mathrm{~L}^{-1}$, ${ }^{12}$ with good selectivity since the measurements could be made in a "ideal" potential window (from a to $-0.200 \mathrm{~V} v s$. SCE), where electrochemical interferences are minimal. The formal potential of meldola's blue, assimilated with the arithmetic mean of cathodic and anodic peak potential, ranges from -0.051 to $-0.175 \mathrm{vs}$. SCE, 
depending on the sensor material and the method used for mediator entrapment. ${ }^{13-16}$

In recent years, the number of reports concerning biosensors based on screen-printed ${ }^{17-20}$ and carbon paste pl-25 $^{21}$ electrodes was continuously increasing and meldola's blue was often a preferred modifier when designing NADH detectors.

Meldola's blue has been physically incorporated into carbon ceramic electrodes and the electrocatalytic oxidation of NADH has been demonstrated. ${ }^{26}$ However, leaching of the mediator is observed during potential cycling.

Actually, there are very few data available in the literature concerning electropolymerization of meldola's blue. For instance, while studying the electrochemical polymerization of different azines, Karyakin et al. ${ }^{27}$ mentioned the formation of only a small amount of electroactive mediator in the case of meldola's blue. Mao and Yamamoto ${ }^{28}$ were the only to have successfully developed modified electrodes based on the electrochemical polymerization of meldola's blue on glassy carbon electrodes. However, their interest was exclusively in developing a peroxidase-based detector for hydrogen peroxide. The authors further used this detector to construct biosensor for glucose and choline, relying on the corresponding oxidases.

Besides these main applications, meldola's blue was used for the determination of ascorbic acid ${ }^{29}$ and even for the detection of pesticids using acethylcholine esterase. ${ }^{30}$

Recently, some work has been published using silica gel or zeolite as inert support matrices of the electron mediator species in carbon paste electrodes. ${ }^{31,32}$ The silicate matrix usually formed by hydrolysis of an alkoxide precursor followed by condensation to yield a polymeric oxo-bridged $\mathrm{SiO}_{2}$ network ${ }^{33}$ and biomolecule is thus encapsulated within the network. This immobilization technique has some advantages over organic polymer supports, including physical rigidity; negligible swelling in both aqueous and organic solution; chemical inertness; high biodegradation, photochemical, and thermal stability; excellent optical transparence. ${ }^{34}$

Studies have demonstrated that meldola's blue can be immobilized on a $\mathrm{SiO}_{2}$ matrix grafted with $\mathrm{TiO}_{2},{ }^{35}$ bulk zirconium phosphate, ${ }^{36,37}$ silica-titanium phosphate, ${ }^{38}$ silica-zirconia-antimonia ${ }^{39}$ or on $\mathrm{SiO}_{2} / \mathrm{Sb}_{2} \mathrm{O}_{3}$ binary oxide matrix ${ }^{40}$ prepared by the sol-gel processing method.

Meanwhile, this technique also suffers from its drawbacks: fragility and film cracking during gelling to xerogel. Several methods were proposed to overcome this drawback and make use of its advantages. The first method was utilizing surfactant to protect the sol-gel film from cracking. ${ }^{41,42}$ The second one was sol-gel derivated ceramic carbon composite materials which was extensively used in amperometric biosensor. ${ }^{43,44}$ The third one was sol-gel derivated inorganic-organic hybrid composite material, which integrated the merits of sol-gel technique and hydrogel entrapment. ${ }^{45}$

Organic modification of sol-gel derivated matrices is used to reduce the degree of cross-link, improve film adhesion to its supports, or introduce reactive functional groups that can be subsequently used for anchoring of molecular recognition species on pre-prepared xerogels. ${ }^{46}$ The sol gel process provides a convenient method for the production of organically modified matrix by incorporating alkoxysilane monomers that contain desirable functional groups in the starting polymerization mixture. ${ }^{47}$

Zhang et al. ${ }^{48}$ studied fictionalized inorganic-organic hybrid material (FIOHM) with meldola's blue incorporated by constructed amperometric hydrogen peroxide. To our best knowledge, no report has been reported on application of the sol-gel derivated inorganic-organic hybrid composite materials incorporating meldola's blue for electrocatalytic oxidation of NADH.

In this present work, the immobilization of the electrons mediator meldola's blue by two different methodologies $(i)$ conducting polypyrrole layer electropolymerized on glassy carbon electrode and (ii) thin films siloxane poly (prolylene oxide) hybrids prepared by sol-gel method and deposited on the graphite electrode surface by dip-coating process were evaluated. The properties of the meldola's blue modified electrodes were investigated by electrocatalytic oxidation of NADH, which can be used as the co-factor for the several enzymes. In the futures of this research will be the application on amperometric biosensor for the lactose using galactose dehydrogenase and $\beta$-galactosidase.

\section{Experimental}

\section{Reagents}

$\beta$-Nicotinamide adenine dinucleotide (NADH) was obtained from Sigma Chemical Co. (St. Louis, MO, USA), poly(propylene glycol) bis-(2-amino-propyl ether) MM 300 and $4000 \mathrm{~mol} \mathrm{~g}^{-1}$ and tetrahydrofurane (THF) were obtained from Aldrich Chemical Company (USA), 3-isocyanatopropyl thietoxy-silane (IsoTrTEOS) and ammonium fluoride were purchased from Fluka Chemie (Switzerland). 7-dimethylamino-1,2-benzophenoxazine (Meldola's Blue, MB) and pyrrole (Py) were purchased from Acros Organics (New Jersey, USA). The pyrrole was previously purified by vacuum distillation at $65^{\circ} \mathrm{C}$, and stored in a nitrogen atmosphere prior to use in order 
to avoid its potential oxidation by atmospheric oxygen. The buffers solution were made up from $\mathrm{Na}_{2} \mathrm{HPO}_{4}$ and $\mathrm{KH}_{2} \mathrm{PO}_{4}$ (phosphate buffer) and piperazine- $N, N^{\prime}$-bis-[2ethanesulfonic acid] (PIPES buffer). All solutions were prepared with deionized water.

\section{Instrumentation}

Electrochemical measurements were carried out by using a PAR 263 potenciostat/galvanostato (EG\&G), Princeton Applied Rechearch Princeton, controlled by a personal computer. The experiments were performed at room temperature $\left(25 \pm 1^{\circ} \mathrm{C}\right)$. A three electrode cell with a volume $2 \mathrm{~mL}$, consisting of a glassy carbon (disc geometry: diameter $2.0 \mathrm{~mm}$ ) or pencil graphite (geometric area, $0.00318 \mathrm{~cm}^{2}$ ), a platinium gauze and $\mathrm{Ag} / \mathrm{AgCl}$ were used, respectively, as working, auxiliary and reference electrode.

Preparation of PPY/MB modified electrode by electropolymerization

The glassy carbon electrode was polished with $0.3 \mu \mathrm{m}$ alumina slurry, followed by washing with distilled water and sonication for $10 \mathrm{~min}$. PPy films were grown onto glassy carbon in PIPES buffer solution $\left(0.1 \mathrm{~mol} \mathrm{~L}^{-1}, \mathrm{pH} 6.8\right)$, containing $0.25 \mathrm{~mol} \mathrm{~L}^{-1}$ of pyrrole and $1.0 \times 10^{-3} \mathrm{~mol} \mathrm{~L}^{-1} \mathrm{MB}$ under $\mathrm{N}_{2}$ atmosphere by cyclic voltammetry (CV) using the following methodology: $\mathrm{CV}$ were scanned from -500 to $700 \mathrm{mV}$ potential (vs. $\mathrm{Ag} / \mathrm{AgCl})$ at $100 \mathrm{mV} \mathrm{s}^{-1}$. After washed with deionized water, it was performed one cycle from -200 to $500 \mathrm{mV}$ at $20 \mathrm{mV} \mathrm{s}^{-1}$, in order to complete the electropolymerization. The electrochemical polymerization parameter such as number of cycles was systematically varied.

The MB in the film was identified by cyclic voltammetry scanned from 500 to $100 \mathrm{mV}$ at $100 \mathrm{mV} \mathrm{s}^{-1}$ for 2 cycles. The stability of the polymer PPy-MB modified electrode was evaluated with 20,40 and 80 cycles. The construction of the analytical curve for NADH was accomplished by amperometric technique $(\mathrm{E}=30$ $\mathrm{mV}$ for $60 \mathrm{~s})$.

Graphite electrode modified by using thin films siloxane poly (propylene oxide) hybrids prepared by sol-gel methods and deposited by dip-coating process

Synthesis of precursors. Siloxane-poly (propylene oxide) PPO nanocomposites were prepared by the sol-gel method as described elsewhere. ${ }^{49}$ Equimolar amounts of 3-isocyanatopropyl thietoxy-silane (IsoTrTEOS) and
0,0'-Bis(2-aminepropyl)-polypropyleneglicol) were stirred with tetrahydrofurane (THF) under reflux for 24 h. THF was evaporated and the hybrid precursor 3(Et O)$\mathrm{Si}$-(PPO)-Si $(\mathrm{OEt})_{3}$ was obtained. PPO polymers with molecular mass of 300 and $400 \mathrm{~g} \mathrm{~mol}^{-1}$ were expressed as PPO 300 and PPO 4000, respectively. $1.0 \mathrm{~g}$ of the precursor was mixed with $2.0 \mathrm{~mL}$ of ethanol containing $\mathrm{NH}_{4} \mathrm{~F}$ resulting to the ration $\left[\mathrm{NH}_{4} \mathrm{~F}\right] /[\mathrm{Si}]=0.001$. Following, $0.4 \mathrm{~mL}$ of deionized water was added under stirring and a sol homogeneous was obtained.

Modification of the graphite electrode surface. The MB was immobilized in thin films siloxane poly (propylene oxide) hybrids prepared by sol-gel method and deposited on the graphite electrode surface by dip-coating ${ }^{50,51}$ process through 2 ways: (i) physical entrapment: $\mathrm{MB}\left(1.0 \times 10^{-3} \mathrm{~mol}\right.$ $\mathrm{L}^{-1}$ ) mixed to PPO 300 or PPO 4000 solutions; (ii) physical adsorption: the graphite electrode was immersed in a solution of MB (1.0x10-3 $\left.\mathrm{mol} \mathrm{L}^{-1}\right)$ during 10, 20 and 30 minutes, following the thin films deposition by dip-coating process; the electrodes were allowed to dry at $4{ }^{\circ} \mathrm{C}$ in a refrigerator for $24 \mathrm{~h}$. Every deposition involved dip and lift speed of $300 \mathrm{~mm} \mathrm{~min}^{-1}$. After drying the electrode, the technique of cyclical voltammetric was applied between -400 and $400 \mathrm{mV}$ at $100 \mathrm{mV} \mathrm{s}^{-1}$, for the identification of the peak of oxidation of the formed film (MB).

After having established these parameters for the formation of the film, the amperometric technique was used for the obtaining of the analytical curve for NADH.

The electrodes were maintained dry at $4{ }^{\circ} \mathrm{C}$, and after 24 $\mathrm{h}$ they were accomplished the NADH amperometric measurements again to verify the stability of the formed film.

\section{Results and Discussion}

Evaluation of the mediation of NADH through the Meldola's blue in solution using a bare glassy carbon electrode

The direct oxidation of NADH on the electrode surface shows a high potential value $(+0.6 \mathrm{~V})$, which provides a lot of reactions interferentes. ${ }^{52}$ This interference phenomenon can be minimized by the use of mediators of electrons (MB) that transfer the electrons of the coenzyme for the electrode surface at a work potential close to $0.0 \mathrm{~V}$, minimizing the interference of other electro active species. ${ }^{53}$ Therefore, the mediations of NADH through the MB in solution using a bare glassy carbon electrode was evaluated.

The NADH mediation process through the phenoxazine meldola blue (MB), following the sequence of reactions (1) to (3).$^{54}$ When NADH finds MB in the surface of the 
electrode, $\mathrm{MB}$ is whole in its oxid form, proportionate condition for the application of a potential always constant on the part of the transdutor. In a first moment there is the formation of a complex between NADH and MB, as presented in the reaction (1):

$\mathrm{NADH}+\mathrm{MB}^{+} \rightleftharpoons \mathrm{NADH} \cdot \mathrm{MB}^{+}$

where NADH is the reduced form of the coenzyme, and $\mathrm{MB}^{+}$is the oxidized form of the mediator Meldola's blue.

Soon afterwards, it happens the chemical reaction of dissociation of the compound, reaction (2):

$\mathrm{NADH} \cdot \mathrm{MB}^{+} \longrightarrow \mathrm{NAD}^{+}+\mathrm{MBH}$

where $\mathrm{NAD}^{+}$is the oxidized form of the coenzyme, and $\mathrm{MBH}$ is the reduced form of the mediator meldola's blue.

Then, mediator reduced forms is electrochemicaly oxidized in the surface of the electrode, and the immediate transfer of the electrons, produces an analytical signal, regenerating the oxidized form of the mediator, reaction (3). The dissociation of the complex is considered the stage limits of this reaction.

$\mathrm{MBH}$

$\mathrm{MB}^{+}+2 \mathrm{e}^{-}+\mathrm{H}^{+}$

In the case of the biosensors containing dehydrogenases, $\mathrm{NAD}^{+}$is always regenerated, allowing the continuous recycling among the species $\mathrm{NADH} / \mathrm{NAD}^{+}$and $\mathrm{MBH} / \mathrm{MB}^{+}$.

Figure 1 shows the oxidation peaks of $\mathrm{MB}$ (a) and NADH (b) at -0.033 and $+0.600 \mathrm{~V}$, respectively. The electrons mediation of NADH through the MB can be observed in Figure 1c. The disappearance of the peak of

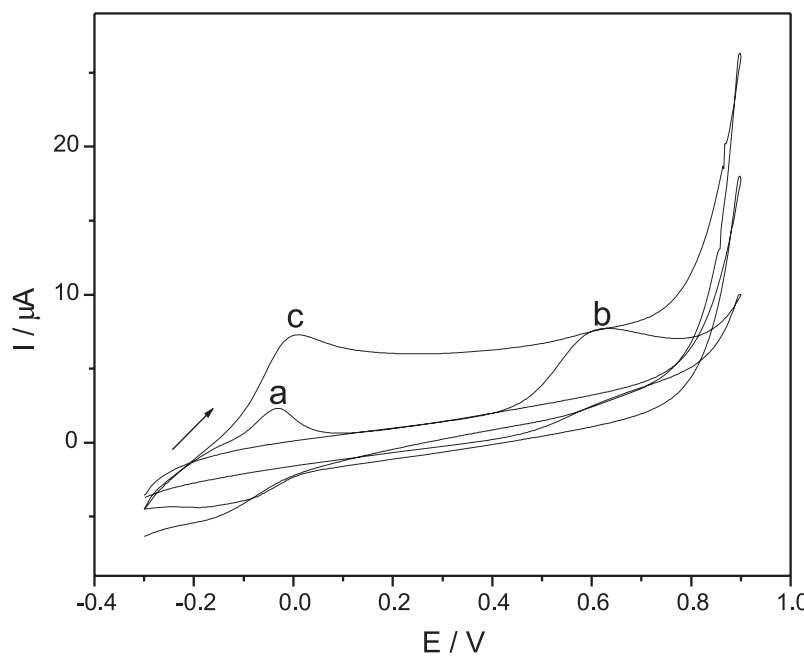

Figure 1. Cyclic voltammograms obtained in $0.1 \mathrm{~mol} \mathrm{~L}^{-1} \mathrm{PIPES}$ buffer solution ( $\mathrm{pH}$ 6.8) containing (a) $\mathrm{MB}\left(1.0 \times 10^{-4} \mathrm{~mol} \mathrm{~L}^{-1}\right)$, (b) NADH $\left(1.0 \times 10^{-3} \mathrm{~mol}\right.$ $\left.\mathrm{L}^{-1}\right)$ and $(\mathrm{c}) \mathrm{MB}\left(1.0 \times 10^{-4} \mathrm{~mol} \mathrm{~L}^{-1}\right)+\mathrm{NADH}\left(1.0 \times 10^{-3} \mathrm{~mol} \mathrm{~L}^{-1}\right)$ using a glassy carbon electrode; scan rate of $100 \mathrm{mVs}^{-1}$ vs. $\mathrm{Ag} / \mathrm{AgCl}$.
$\mathrm{NADH}$ and the increase of the current intensity close to potential of the MB mediator $(-0.003 \mathrm{~V})$ evidenced the process of electrons transfer of $\mathrm{NADH}$ on the electrode surface.

Modification of the glassy carbon electrode surface by electropolymerization of the pyrrol and Meldola's blue

The PPy/MB modified electrode surface was prepared following the literature procedure, ${ }^{55}$ which describes the use of Pt-Ir microelectrode, as work electrode and the mediator $\mathrm{MB}$, concluding that the film formed above $0.600 \mathrm{~V}$ would provides the superoxidation of the polypyrrol provoking bad definition in the signal of oxidation of the present mediator in the film.

The influence of PPy film thicknesses on the MB modified electrode response was controlled by number of cycles (10, 25 and 50 cycles) of the cyclic voltammograms. The ratio of anodic to cathodic peak currents obtained increase linearly with the amount of cycles. Thus, the number of cycles affects the amount of MB immobilized in the PPy films. However a couple of well-defined redox peaks the film of the PPy/MB film formed with 50 cycles were observed. In order to investigate the film stability each PPy film formed under those conditions were submitted to 20, 40 and 80 successive cycles in $0.1 \mathrm{~mol} \mathrm{~L}^{-1}$ PIPES buffer solution pH 6.8, as presented in the Table 1 .

Table 1. Results obtained with GCE/PPy/MB modified electrode

\begin{tabular}{cccccc}
\hline $\begin{array}{l}\text { Number of cycles } \\
\text { (formation of the film) }\end{array}$ & $\mathrm{E}_{\mathrm{pa}}(\mathrm{V})$ & $\mathrm{I}(\mu \mathrm{A})$ & \multicolumn{3}{c}{$\begin{array}{c}\text { Decrease of the } \\
\text { current intensity }(\%)\end{array}$} \\
\hline & & \multicolumn{4}{c}{20 cycles 40 cycles 80 cycles } \\
10 & -0.030 & 4.65 & 9 & 13 & 13 \\
25 & -0.067 & 9.54 & 13 & 16 & 19 \\
50 & -0.052 & 13.89 & 15 & 21 & 22 \\
\hline
\end{tabular}

As shown in Table 1 the PPy/MB film formed with 10 cycles presented the smallest percentage of loss of the current intensity after 20, 40 and 80 cycles, however, it was not obtained a defined redox peaks by cyclic voltammetry. In comparison to the film formed with 25 and 50 cycles it was observed that both presented couple very defined redox, however the film formed with 25 cycles, the percentage of loss of the current intensity was smaller than the film formed with 50 cycles after the test of stability (Table 1 ).

Sequentially, analytical performance of the GCE/PPy/ $\mathrm{MB}$ sensor in the determination of NADH was accomplished by amperometric technique ( $\mathrm{E}=30 \mathrm{mV}$ for $60 \mathrm{~s}$ ). PPy/MB modified electrodes response was obtained under different concentration of NADH ranging from $1.0 \times 10^{-6}$ to $1.7 \times 10^{-4}$ mol L-1. The analytical curves were plotted by average of at 
least 3 current intensity values. Table 2 summarizes the analytical performance of the sensor, obtained under the optimum experimental conditions. The detection limit (LD) for NADH was calculated as $\mathrm{LD}=3 \pm \mathrm{SD}$ (standard deviation) ${ }_{\text {blanck }} /$ sensitivity. The sensitivity was obtained by slope of the fitted line the films formed with 10 cycles $(\mathrm{y}=$ $\left.2.46 \times 10^{-7} \mathrm{x}+0.004\right), 25$ cycles $\left(\mathrm{y}=6.0 \times 10^{-7} \mathrm{x}+0.003\right)$ and 50 cycles $\left(\mathrm{y}=1.20 \mathrm{x} 10^{-6} \mathrm{x}+0.003\right)$.

It was observed, that the films formed with 10 and 25 cycles presented linear range more extended than with the film formed with 50 cycles. Likewise, the film formed with 25 cycles presented smallest LD and RSD, favorable conditions for analytical detection.

Modification of the graphite electrode surface with $M B$ in thin films siloxane poly (propylene oxide) hybrids prepared by sol-gel method

Firstly, it was performed the immobilization of the MB $\left(1.0 \times 10^{-3} \mathrm{~mol} \mathrm{~L}^{-1}\right)$ by physical entrapment in the precursors PPO (MM 300 and 4000). The influence of the chain size of precursors PPO 300 and PPO 4000 was evaluated. The Figure 2 shows that the film formed in the presence of PPO 300 and MB (Figure 2, a) presented better definition of the oxidation peak $\left(\mathrm{E}_{\mathrm{pa}}=0.038 \mathrm{~V}\right)$ than the film formed with PPO 4000 and MB (Figure 2, b).

Following, the process eletrocalytic between the molecule of NADH and the system PPO 300-MB was investigated. The measurements were accomplished through the amperometric technique $\left(\mathrm{E}_{\text {applied }}=0.003 \mathrm{~V}\right)$ and the modified electrode response decreased with the increase of the NADH. Therefore, it was not observed the electrocatalytic process between NADH and the system PPO 300-MB in the graphite electrode.

Another way to modify the graphite electrode was studied. The MB $\left(1.0 \times 10^{-3} \mathrm{~mol} \mathrm{~L}^{-1}\right)$ was firstly adsorbed on graphite electrode surface during 10, 20 and 30 minutes. After that the polymeric precursors (PPO 300 or 4000) were deposited by dip-coating process. Figure 3 shows the effect of time adsorption of $\mathrm{MB}$ onto the graphite electrode and subsequently recovered by PPO 300 (Figure $3 \mathrm{~A}$ ) or PPO 4000 (Figure 3B). Oxidation peaks of $\mathrm{MB}$ in 10 minutes $\left(\mathrm{E}_{\mathrm{pa}}=100 \mathrm{mV}\right.$ and $\left.\mathrm{I}=75 \mu \mathrm{A}\right), 20$ minutes $\left(\mathrm{E}_{\mathrm{pa}}=30 \mu \mathrm{V}\right.$ and $\mathrm{I}=80 \mu \mathrm{A})$ and with 30 minutes $\left(\mathrm{E}_{\mathrm{pa}}=30 \mu \mathrm{V}\right.$ and $\mathrm{I}=79$

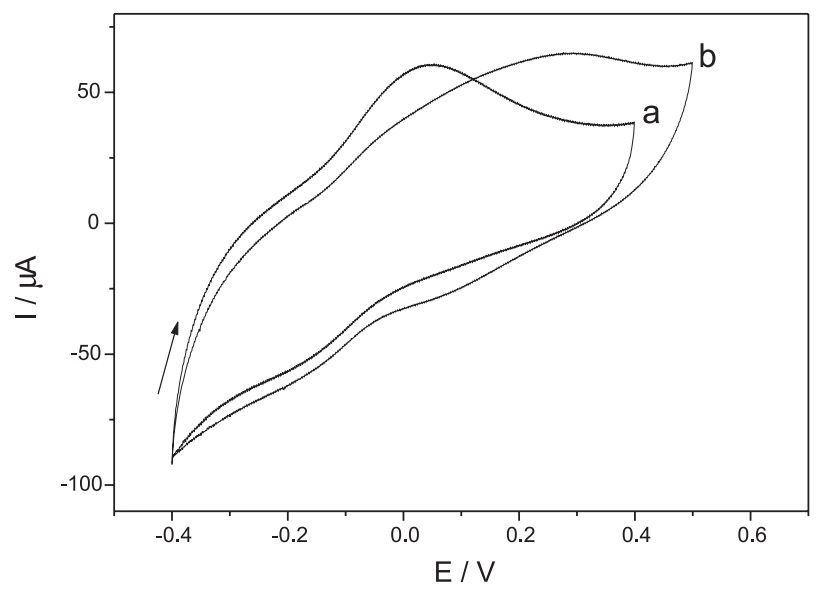

Figure 2. Cyclic voltammograms of the graphite electrode modified with PPO 300-MB (a) and PPO 4000-MB (b) in $0.1 \mathrm{~mol} \mathrm{~L}^{-1}$ PIPES buffer solution ( $\mathrm{pH}$ 6.8); scan rate of $100 \mathrm{mV} \mathrm{s}^{-1} v$ s. $\mathrm{Ag} / \mathrm{AgCl}$.

$\mu \mathrm{A}$ ) were obtained for the PPO 300 system. Figure 3B shows that the acquired results were unsatisfactory, because a bad definition in the peaks of MB oxidation/reduction was obtained. With that, it was ended that the precursor PPO 4000 was not favorable in the formation of the film. This fact can be related with the size of the polymeric chain that is the organic part of the molecule that influences the speed of evaporation of the solvent and compacting of the polymeric chains strongly, as well as, the size of the formed pores, these are directly proportional to such organic chain. The process of evaporation of the solvent is faster in the polymeric chains of low molecular weight driving it a mechanism of drying of the most regular film. Besides, our workgroup has also studied the immobilization of the streptavidin (STA) protein into the PPO 300 and PPO 4000 precursors. It was observed a better response when the STA was immobilized into the PPO 4000. As the PPO 4000 presents a large size of the polymeric chain could be favorable to STA immobilization. On the other hand, the MB mediator which presented molecular mass of $379 \mathrm{~g}$ $\mathrm{mol}^{-1}$ probably require a polymeric chain smaller size than PPO 300 and, consequently, a better orientation of the immobilized MB molecule.

The analytical curve for NADH was performed using the MB/PPO 300 modified electrode by amperommetry, following potentials: 100,30 and $20 \mathrm{mV}$ for the submerged electrode in MB during 10, 20 and 30 min, respectively.

Table 2. Analytical performance of the GCE/PPy/MB sensor in the determination of NADH

\begin{tabular}{|c|c|c|c|c|c|}
\hline $\begin{array}{l}\text { Number of cycles } \\
\text { (formation of the film) }\end{array}$ & $\begin{array}{l}\text { Detection Limit } \\
\left(\mathrm{mol} \mathrm{L}^{-1}\right) \mathrm{n}=3\end{array}$ & $\begin{array}{l}\text { Linear range } \\
\left(\mathrm{mol} \mathrm{L}^{-1}\right)\end{array}$ & $\begin{array}{l}\text { Relative Standard } \\
\text { Deviation (RSD)\% }\end{array}$ & $\mathrm{R}$ & $\begin{array}{c}\text { Sensitivity } \\
\left(\mu \mathrm{A} \text { per } \mathrm{mol} \mathrm{L}^{-1}\right)\end{array}$ \\
\hline 10 & $4.2 \times 10^{-7}$ & $1.0-9.0 \times 10^{-6}$ & $5.23 \%$ & 0.9852 & 0.004 \\
\hline 25 & $3.5 \times 10^{-7}$ & $1.0-9.0 \times 10^{-6}$ & $1.14 \%$ & 0.9753 & 0.003 \\
\hline 50 & $2.3 \times 10^{-5}$ & $1.0-3.0 \times 10^{-6}$ & $7.06 \%$ & 0.9323 & 0.003 \\
\hline
\end{tabular}


The constant potentials were applyed for $60 \mathrm{~s}$. The MB/ PPO 300 modified electrode response was proportional to NADH concentration followed two linear intervals, as shown in the Table 3.

The eletrocatalytic process between NADH and the system MB (immersion)-PPO 300 (dip-coating) in the graphite electrode was observed.

The PPO 300 modified electrode immersed in MB solution for 30 min showed lower detection limit. The linear range was the same in all of the appraised immobilization conditions. The sensitivity of the system
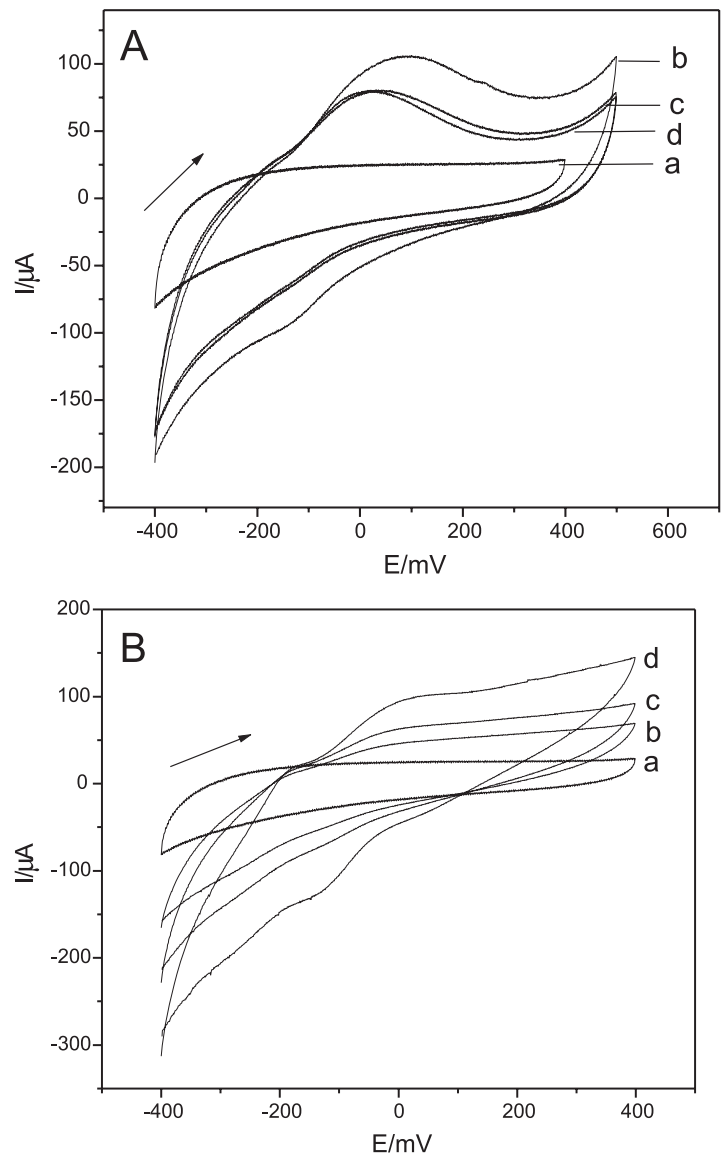

Figure 3. Cyclic voltammograms of $0.1 \mathrm{~mol}$ L PIPES buffer solution $(\mathrm{pH}$ 6.8) using the graphite electrode modified with PPO 300 (3A, a) and MB $\left(1.0 \times 10^{-3} \mathrm{~mol} \mathrm{~L}^{-1}\right)$ adsorption for $10(3 \mathrm{~A}, \mathrm{~b}), 20(3 \mathrm{~A}, \mathrm{c})$ and $30(3 \mathrm{~A}, \mathrm{~d})$ min (B) followed by PPO 300 dip-coating and PPO 4000 (3B, a) and MB $\left(1.0 \times 10^{-3} \mathrm{~mol} \mathrm{~L}^{-1}\right)$ adsorption for $10(3 \mathrm{~B}, \mathrm{~b}), 20(3 \mathrm{~B}, \mathrm{c})$ and $30(3 \mathrm{~B}, \mathrm{~d})$ min followed by PPO 4000 dip-coating. was defined by slope of the fitted line in which a difference was observed no significant in the response of each studied condition (Table 3).

The physical entrapment and physical adsorption for the modification of the MB/PPO 300 electrode were compared. It was verified that the method of physical adsorption of MB following by the deposit of PPO 300 showed more favorable for the oxidation electrocatalytic of NADH. The reason of the physical entrapment method has not presented a good NADH response, it can be related with many parameters in the synthetic protocol such as: hydrolysis ratio, hydrolysis and condensation catalyst, mixing mode and optimal time for entrapment ${ }^{56}$ and also because de NADH molecule size.

\section{Stability of the film formed by sol-gel method}

The graphite electrodes modified with the system MB (immersion)-PPO 300 (dip-coating) were dry stored at $4{ }^{\circ} \mathrm{C}$ during 24 hours. After that, the voltammetric and amperometric measurement were accomplished to verify the time of drying in the response of the film and the stability of the film. The current intensity as well as the cathodic peak for the electrode after 2 and $24 \mathrm{~h}$ are displayed on Table 4. It was observed an increase in the current intensity from of $10^{-8}$ for $10^{-7} \mathrm{~A}$. Thus, a significant improvement of the response of the electrode after a time of drying of the film for 24 hours was obtained.

Table 4. Values of current intensity obtained by cyclic voltammetry of the MB/PPO 300 modified electrode

\begin{tabular}{crcrr}
\hline $\begin{array}{l}\text { Time of immersion } \\
\text { in } 1 \times 10^{-4} \mathrm{~mol} \mathrm{~L}^{-1}\end{array}$ & \multicolumn{2}{c}{ After $2 \mathrm{~h}$} & \multicolumn{2}{c}{ After 24 h } \\
MB solution (min) & $\begin{array}{c}\mathrm{E}_{\mathrm{PC}} \\
(\mathrm{mV})\end{array}$ & $\begin{array}{c}\mathrm{I} \\
(\mathrm{A})\end{array}$ & $\begin{array}{c}\mathrm{E}_{\mathrm{PC}} \\
(\mathrm{mV})\end{array}$ & $\begin{array}{c}\mathrm{I} \\
(\mathrm{A})\end{array}$ \\
\hline 10 & 100 & $7.5 \times 10^{-8}$ & 70 & $10.5 \times 10^{-7}$ \\
20 & 30 & $8.0 \times 10^{-8}$ & 30 & $7.9 \times 10^{-7}$ \\
30 & 30 & $7.9 \times 10^{-8}$ & 30 & $7.9 \times 10^{-7}$ \\
\hline
\end{tabular}

Following, the same procedure described above was used to the construction of the analytical curve of NADH by amperometric technique at $70 \mathrm{mV}$ for the immersed electrode in $\mathrm{MB}$ during $10 \mathrm{~min}$ and $30 \mathrm{mV}$ for the immersed electrodes in MB during 20 and 30 min. As shown in Figure

Table 3. Analytical performance of the MB/ PPO 300 sensor in the determination of NADH

\begin{tabular}{|c|c|c|c|c|c|c|c|c|c|}
\hline \multirow{2}{*}{$\begin{array}{l}\text { Time of immersion } \\
\text { electrode in } 1 \times 10^{-3} \mathrm{~mol} \mathrm{~L}^{-1} \\
\text { MB solution }(\mathrm{min})\end{array}$} & \multicolumn{2}{|c|}{$\begin{array}{l}\text { Detection Limit } \\
\left(\mathrm{mol} \mathrm{L}^{-1}\right) \mathrm{n}=3\end{array}$} & \multicolumn{2}{|c|}{$\begin{array}{l}\text { Linear range } \\
\left(\mathrm{mol} \mathrm{L}^{-1}\right)\end{array}$} & \multirow[t]{2}{*}{$\begin{array}{l}\text { Relative Standard } \\
\text { Deviation (RSD)\% }\end{array}$} & \multicolumn{2}{|c|}{$\mathrm{R}$} & \multicolumn{2}{|c|}{$\begin{array}{c}\text { Sensitivity } \\
\left(\mu \mathrm{A} \text { per } \mathrm{mol} \mathrm{L}^{-1}\right)\end{array}$} \\
\hline & $1^{\text {st }}$ fit & $2^{\text {nd }}$ fit & $1^{\text {st }}$ fit & $2^{\text {nd }}$ fit & & $1^{\text {st }}$ fit & $2^{\text {nd }}$ fit & $1^{\text {st }}$ fit & $2^{\text {nd }}$ fit \\
\hline 10 & $4.8 \times 10^{-7}$ & $1.4 \times 10^{-6}$ & $1.0-9.0 \times 10^{-6}$ & $9.0 \times 10^{-6}-1.7 \times 10^{4}$ & 3.0 & 0.977 & 0.995 & $2.2 \times 10^{-3}$ & $7.57 \times 10^{-4}$ \\
\hline 20 & $3.7 \times 10^{-7}$ & $1.9 \times 10^{-6}$ & $1.0-9.0 \times 10^{-6}$ & $9.0 \times 10^{-6}-1.7 \times 10^{4}$ & 3.5 & 0.963 & 0.989 & $3.6 \times 10^{-3}$ & $6.87 \times 10^{-4}$ \\
\hline 30 & $1.9 \times 10^{-7}$ & $1.1 \times 10^{-6}$ & $1.0-9.0 \times 10^{-6}$ & $9.0 \times 10^{-6}-1.7 \times 10^{4}$ & 2.5 & 0.966 & 0.997 & $4.0 \times 10^{-3}$ & $6.85 \times 10^{-4}$ \\
\hline
\end{tabular}


4 , the response with electrodes prepared by immersion during 20 and 30 min showed a smaller linear range and lower current intensity than $10 \mathrm{~min}$, probably because the higher amounts of mediator adsorbed with the time of the immersion. After $9.0 \times 10^{-6} \mathrm{~mol} \mathrm{~L}^{-1} \mathrm{NADH}$, the current intensities are almost constant for electrodes prepared with 20 and $30 \mathrm{~min}$ immersion. This behavior can be explained by the energy necessary to oxidize the mediator excess, damaging the formation of the film. These resulted were observed also in the work developed for Pereira et al..$^{55}$ On the other hand for $10 \mathrm{~min}$ immersed electrode the values of current intensity increased proportionally with the NADH concentration and presented two linear range: ( $1^{\text {st }}$ fit - lower concentration and $2^{\text {nd }}$ fit - high concentrations) (Figure 4). The sensitivity was defined by slope of the fitted line as $3.0 \times 10^{-3}$ and $1.0 \times 10^{-3} \mu \mathrm{A}$ per mol $\mathrm{L}^{-1}$, detection limit of $3.5 \times 10^{-7}$ and $7.1 \times 10^{-7} \mathrm{~mol} \mathrm{~L}^{-1}$, linear range of $1.0 \times 10^{-6}$ $2.0 \times 10^{-5}$ and $2.0 \times 10^{-5}-1.7 \times 10^{-4}$ and $\mathrm{R}$ was 0.995 and 0.969 for lower and high concentrations, respectively. The relative standard deviation was $0.29 \%$. Therefore, the best conditions were established as time of immersion electrode in $\mathrm{MB}$ solution of $10 \mathrm{~min}$ with the storage in dry at $4^{\circ} \mathrm{C}$ for 24 hours instead of $30 \mathrm{~min}$ when the measurement has done after drying the polymer during 2 hour.

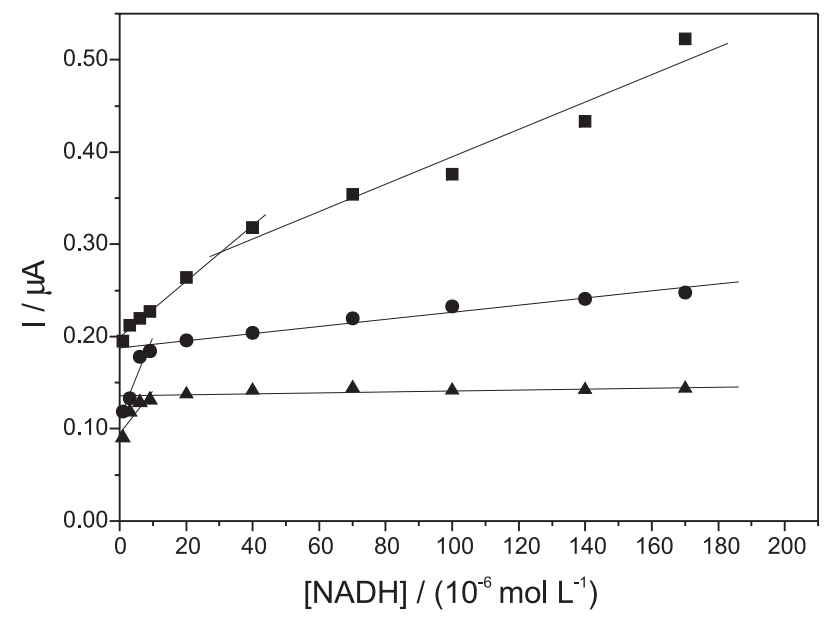

Figure 4. Analytical curves for NADH obtained by amperometric tech-

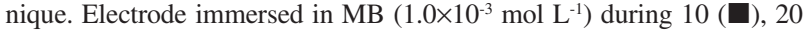
(-) and 30 ( $\mathbf{\Delta})$ min followed by PPO 300, after 24 hours storage.

\section{Conclusions}

The present studies confirmed the electrocatalytic properties of $\mathrm{MB}$ in relation to the process of mediation of NADH (in the soluble form). The oxidation potential of NADH, in the presence of MB, decreases from 600 $\mathrm{mV}$ to close potential of the mediator $(0.003 \mathrm{~V})$.

In relation to the polypyrrole film formed in the presence of MB by electrodeposition could be concluded that the formed film by voltammetric technique with 25 cycles showed a better response in respect to stability and electrocatalytic properties with NADH, with detection limit of $3.5 \times 10^{-7} \mathrm{~mol} \mathrm{~L}^{-1}$, linear range of $1.0-9.0 \times 10^{-6} \mathrm{~mol}$ $\mathrm{L}^{-1}$ and relative standard deviation (RSD) of $1.14 \%$.

A new methodology was proposed, using a modified graphite electrode with the precursors PPO 300 and PPO 4000 deposited by dip-coating process. Just the PPO 300 was suitable for MB entrapment into the polymeric film but there is no catalytic reaction with the NADH.

The adsorption of MB onto the graphite and subsequent deposition of PPO 300 or PPO 4000 indicated that PPO 4000 was not favorable for the mediated reaction but the methodology studied with the system PPO300 presented more favorable for the transfer of electrons of NADH. Besides, the formed film presented two linear response zone, with detection limit of $3.5 \times 10^{-7}$ and $7.1 \times 10^{-7} \mathrm{~mol} \mathrm{~L}^{-1}$, linear range of $1.0 \times 10^{-6}-2.0 \times 10^{-5} \mathrm{~mol} \mathrm{~L}^{-1}$ and $2.0 \times 10^{-5}-1.7 \times 10^{-4}$ for low and high concentrations, respectively. The relative standard deviation (RSD) of $0.29 \%$ and the sensitivity of $3.0 \times 10^{-3} \mathrm{~mA}$ per $\mathrm{mol} \mathrm{L}^{-1}$ (low concentrations) and $1.0 \times 10^{-3}$ $\mathrm{mA}$ per $\mathrm{mol} \mathrm{L}^{-1}$ (high concentrations) were obtained.

The adsorption of MB followed by PPO 300 deposition presented broader linear range than PPy methodology.

\section{Acknowledgments}

We thank FAPESP for financial support (Proc. 00/ 10533-6) and Dr. C.V. Santilli and Dr. K. Dahmouche for technical assistence.

\section{References}

1. Gorton, L.; Csoregi, E.; Dominguez, E.; Emneus, J.; JonssonPettersson, G.; Marko-Varga, G.; Persson, B.; Anal. Chim. Acta 1991, 250, 203.

2. Karyakin, A.A.; Ivanova, Y.N.; Revunova, K. V.; Karyakina, E.E.; Anal. Chem. 2004, 76, 2004.

3. Munteanu, F.D.; Mano, N.; Jun, A.; Gorton, L.; J. Electroanal. Chem. 2004, 564, 167.

4. Gorton, L.; J. Chem. Soc. Faraday Trans. 1986, 82, 1245.

5. Ueda, C.; Tes, D. C-S.; Kuwana, T.; Anal. Chem. 1982, 54, 850 .

6. Torstensson, A.; Gorton, L.; J. Electroanal. Chem. 1981, 130, 199.

7. Huck, H.; Schelter-Graf, A.; Schmidt, H.L.; Bioelectronics Chem. Bioenerg. 1984, 13, 199.

8. Gorton, L.; Torstensson, A.; Jaegfeldt, H.; Johansson, G.; J. Electroanal. Chem. 1984, 161, 103.

9. Bremle, G.; Persson, B.; Gorton, L.; Electroanalysis 1991, 3, 77. 
10. Jaegfeldt, H.; Torstensson, A.; Gorton, L.; Johansson, G.; Anal. Chem. 1981, 53, 1979.

11. Miki, K.; Ikeda, T.; Todoriki, S.; Senda, M.; Anal. Sci. 1989, 5, 269.

12. Wang, J.; Pamidi, P.V.A.; Jiang, M.; Anal. Chim. Acta 1998, 360, 171.

13. Zhang, J.; Li, B.; Wang, Z.; Cheng, G.; Dong, S.; Anal. Chim. Acta 1999, 388, 71.

14. Monteanu, F.D.; Kubota, L.T.; Gorton, L.; J. Electroanal. Chem. 2001, 509, 2.

15. Bremle, G.; Persson, B.; Gorton, L.; Electroanalysis 1991, 3, 77.

16. Persson, B.; Gorton, L.; J. Electroanal. Chem. 1990, 292, 115.

17. Wedge, R.; Pemberton, R.M.; Hart, J.P.; Luxton, R.; Analysis 1999, 27, 570 .

18. Sandstrom, K.J.M.; Newman, J.; Sunesson, A-L.; Levin, J-O.; Turner, A.P.F.; Sens. Actuators B 2000, 70, 182.

19. Avramescu, A.; Andreescu, A.; Noguer, T.; Bala, C.; Andreescu, D.; Marty, J-L.; Anal. Bioanal. Chem. 2002, 374, 25.

20. Vasilescu, A.; Andreescu, S.; Bala, C.; Litescu, S.C.; Noguer, T.; Marty, J.L.; Biosens. Bioelectronics 2003, 18, 781.

21. Kulys, J.; Gleixner, G.; Schuhmann, W.; Schmidt, H.L.; Electroanalysis 1993, 5, 201.

22. Lobo, M.J.; Miranda, A.J.; Tunon, P.; Electroanalysis 1996, 8,591

23. Kubota, L.T.; Gorton, L.; Electroanalysis 1999, 11, 719.

24. Santos, A.S.; Gorton, Lo.; Kubota, L.T.; Electroanalysis 2002, 14,79 .

25. Ladiu, C.I.; Popscu, I.C.; Gorton, Lo.; Electrochemistry 2005, 9, 296.

26. Sampath, S.; Lev, O.; Electroanal. Chem. 1997, 446, 57.

27. Karyakin, A.A.; Karyakina, E.E.; Schmidt, H-L.; Electroanalysis 1999, 11, 149

28. Mao, L.; Yamamoto, K.; Talanta 2000, 51, 187.

29. Suzuki, M.; Umetani, S.; Matsui, M.; Kihara, S.; J. Electroanal. Chem. 1997, 420, 119.

30. Khayyami, M.; Perez Pita, M.T.; Garcia, N.P.; Johansson, G.; Danielsson, B.; Larson, P-O.; Talanta 1998, 45, 557.

31. Teixeira, M.F.S.; Bergamini, M.E.; Marques, C.M.P.; Bocchi, N.; Talanta 2004, 63, 1083.

32. Santos, A.S.; Duran, N.; Kubota, L.T.; Electroanalysis 2005 , 17, 1103.

33. Dave, B.C.; Dunn, B.; Valentine, J.S.; Zink, J.I.; Anal. Chem. 1994, 66, 1120

34. Lev, O.; Tsionsky, M.; Rabinovich, L.; Glezer, V.; Sampath, S.; Pankratov, I.; Gun, J.; Anal. Chem. 1995, 67, 22.
35. Kubota, L.T.; Gouveia, F.; Andrade, A.N.; Milagres, B.G.; Oliveira, Neto, G.; Electrochim. Acta 1996, 41, 1465.

36. Pessoa, C.A.; Gushikem, Y.; Kubota, L.T.; Electroanalysis 1997, 9, 800.

37. Pessoa, C.A.; Gushikem, Y.; Kubota, L.T.; Gorton, L.; Electroanal. Chem. 1997, 431, 23.

38. Ferreira, C.U.; Gushikem, Y.; Kubota, L.T.; J. Solid State Electrochem. 2000, 4, 298.

39. Zaitseva, G.; Gushikem, Y.; Ribeiro, E.S.; Rosatto, S.S.; Electrochim. Acta 2002, 47, 1469.

40. Ribeiro, E.S.; Rosatto, S.S.; Gushikem, Y.; Kubota, L.T.; J. Solid State Electrochem. 2003, 7, 665.

41. Chut, S.L.; Li, J.; Tan, S.N.; Analyst 1997, 122, 1431.

42. Lev, O.; Analusis 1992, 20, 543.

43. Wang, J.; Pamidi, P.V.A.; Park, D.S.; Electranalysis 1997, 9 , 52.

44. Li, J.; Tan, S.N.; Ge, H.; Anal. Chim. Acta 1996, 335, 137.

45. Wang, B.Q.; Li, B.; Deng, Q.; Dong, S.J.; Anal. Chem. 1998, 70,3170 .

46. Lev, O.; Tsionsky, M.; Rabinovich, L.; Glezer, V.; Sampath, S.; Pankratov, I.; Gun, J.; Anal. Chem. 1995, 67, 22.

47. Philipp, G.; Schidt, H.; J. Non-Cryst. Solids 1984, 63, 283.

48. Zhang, J.; Li, B.; Wang, Z.; Cheng, G.; Dong, S.; Anal. Chim. Acta 1999, 388, 71.

49. Dahmouche, K.; Santilli, C.V.; Pulcinelli, S.H.; Craiveiche, A.C.; J. Phys. Chem. B 1999, 103, 4937.

50. Galasso, F.S.; Structure, Properties and Preparation of Perovskite-Type Compounds, Pergamon Press: Oxford, Pergamon Press, 1969, p. 207.

51. Wu, L.; Wu, T.S.; Wei, C.C.; Lui, H.C. J. Phyis. C Solid State 1983, 16, 2823.

52. Chi, Q.; Dong, S.; Analyst 1994, 119, 1063.

53. Nascimento, V.B.; Angnes, L.; Quim. Nova 1998, 21, 614.

54. Sprules, S.D.; Hart, J.P.; Pittson, R.; Wring, S.A.; Electroanalysis 1996, 8, 539.

55. Pereira, A.C.; Fertonani, F.L.; Neto, G.D.; Kubota, L.T.; Yamanaka, H.; Talanta 2001, 53, 801.

56. Arsene, M.L.; Stanciu, L.; Parlog.; C. Revue Roumaine de Chimie 2002, 46, 757.

Received: August 4, 2005 Published on the web: May 11, 2006

FAPESP helped in meeting the publication costs of this article. 